\title{
ARTERIAL BLOOD PRESSURES AND HYPERTENSION IN AN URBAN AFRICAN POPULATION SAMPLE
}

\author{
T. OSOTAYO JOHNSON
}

Department of Medicine, College of Medicine, University of Lagos, Private Mail Bag 12003, Lagos, Nigeria

In the last three decades increasing attention has been paid to a systematic study of arterial blood pressures and hypertension in the native African. The recent reports have shown that, contrary to the opinions of earlier authors (Donnison, 1929; Vint, 1937; Kenney and Watkins, 1956), hypertension commonly affects Africans (see Symposium on Blood Pressure and Hypertension in Africa, 1969) and already certain peculiarities of the disorder are being described in them (Akinkugbe, 1968, 1969).

For many reasons, nearly all the community studies have concerned rural groups of Africans, and worth-while studies in well-defined, unselected, and representative urban communities are few.

This paper describes the results of a study of the distribution of arterial blood pressures and the prevalence and familial occurrence of hypertension in an urban West African population sample.

\section{Area of Study}

Lagos, the capital of the Federal Republic of Nigeria, is an urban area, largely over-crowded, cosmopolitan, and fast growing. The pattern of its health problems is slowly evolving into that of a town in the more socially advanced parts of the world.

Since 1967, the Department of Community Health of the Lagos University College of Medicine has maintained 30 survey sample blocks chosen on a random systematic basis as a 'Community Health Laboratory'. The areas of the present study were chosen for the author at random from these survey blocks to give a sample closely representative of the entire 'Lagos community sample'.

\section{SubJects ANd Methods of Study}

All the permanent inhabitants aged 10 years and above in this sub-sample were considered for the study, but, during the survey, subjects who had travelled from their homes for more than 12 weeks were excluded. All the respondents were examined in their homes by the author and many of them were already familiar with him from previous surveys. Also, many of the women in the child-bearing age had at one time or another had their blood pressures $\vec{\circ}$ taken in hospital or maternity clinics and were fully $\overrightarrow{\vec{H}}$ aware of the painless procedure involved. Eacho subject was questioned about age, marital ando educational status, present or immediate past oc-? cupations, and exact relationship in the household N The subjects were examined as seen and not in anyparticular order of age or seniority in the household N

The physical measurements taken on subjects ine this sample population have already been described. (Johnson, $1970 \mathrm{a}, \mathrm{b}$ ). The subjects sat relaxed forT at least 5 minutes before the blood pressures wereo recorded. Readings were taken on a portable mercury sphygmomanometer and recorded to the nearest 5 or $10 \mathrm{mmHg}$ gradation below the observed figure. The systolic figure was taken at the first pearance of the sound and an abrupt fading $\& \mathrm{r}_{\square}$ muffling of the sounds (phase IV) was taken as theo index of diastolic pressure.

In order to ensure accuracy, a pressure cuff witho a bladder $12.5 \mathrm{~cm}$ wide by $22 \mathrm{~cm}$ long was applieco snugly $2-3 \mathrm{~cm}$ above the antecubital fossa in alp subjects. The arm bared and with no constriction $\vec{B}$ was supported at the level of the heart at an angle of about $45^{\circ}$ away from the trunk. All measurements were taken on the right arm, except in two of the subjects.

\section{RESULtS}

SAmple Statistics

Table I shows the age and sex composition of thes

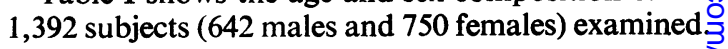

TABLE I

AGE AND SEX DISTRIBUTION OF SUBJECTS

\begin{tabular}{|c|c|c|c|c|c|}
\hline \multirow{2}{*}{$\underset{\text { (years) }}{\text { Age Group }}$} & \multicolumn{2}{|c|}{ Males } & \multicolumn{2}{|c|}{ Females } & N \\
\hline & No. & $\%$ & No. & $\%$ & N \\
\hline $\begin{array}{l}10-19 \\
20-29 \\
30-39 \\
40-49 \\
50-59 \\
60-69 \\
70+\end{array}$ & $\begin{array}{r}150 \\
197 \\
111 \\
96 \\
48 \\
27 \\
13\end{array}$ & $\begin{array}{r}23 \cdot 4 \\
30 \cdot 7 \\
17 \cdot 3 \\
15 \cdot 0 \\
7 \cdot 5 \\
4 \cdot 2 \\
2 \cdot 0\end{array}$ & $\begin{array}{r}220 \\
198 \\
153 \\
90 \\
47 \\
20 \\
22\end{array}$ & $\begin{array}{r}29 \cdot 3 \\
26.4 \\
20 \cdot 4 \\
12 \cdot 0 \\
6 \cdot 3 \\
2.7 \\
2.9\end{array}$ & 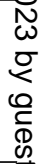 \\
\hline Total & 642 & & 750 & & \\
\hline & & & & & $\begin{array}{l}\text { Dे } \\
\stackrel{\rho}{\mathbb{D}} \\
\varrho\end{array}$ \\
\hline
\end{tabular}




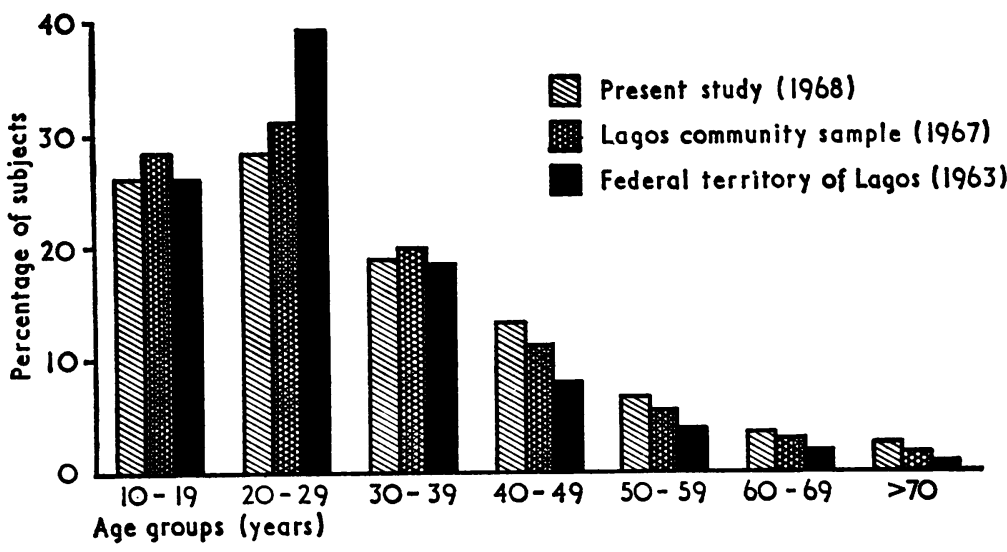

FIG. 1. Comparison of age structure of subjects in present study (1968) Lagos Community Sample (1967). and the Federal Territory of Lagos (1963).

Ages ranged from 10 to 102 years. Figure 1 compares the age structure of the studied group with those of the entire 'Lagos Sample' (Morgan, 1967) and the Federal Territory of Lagos (Federal Department of Statistics, 1963) for subjects aged 10 years and above. The overall response rate was good. Nine refusals were encountered.

\section{EDUCATION AND OCCUPATION}

The education and occupation classifications of the subjects are given in Table II. Males had better

TABLE II

EDUCATION AND OCCUPATION CLASSIFICATIONS OF SURVEY SUBJECTS

\begin{tabular}{c|c|c|c}
\hline Sex & $\begin{array}{c}\text { No } \\
\text { Schooling }\end{array}$ & $\begin{array}{c}\text { Primary } \\
\text { School }\end{array}$ & $\begin{array}{c}\text { Beyond } \\
\text { Primary } \\
\text { School }\end{array}$ \\
\hline M (\%) & 23.5 & 51.7 & $\begin{array}{c}54.8 \\
\text { F (\%) }\end{array}$ \\
\hline Both sexes & 46.1 & 44.4 & 9.5 \\
\hline & 35.7 & 47.8 & 16.5 \\
\hline
\end{tabular}

\begin{tabular}{l|c|c|c|c}
\hline \multicolumn{1}{c|}{ Sex } & $\begin{array}{c}\text { Skilled and } \\
\text { Professional } \\
\text { Occupations }\end{array}$ & $\begin{array}{c}\text { Semi- } \\
\text { skilled }\end{array}$ & Unskilled & Unemployed \\
\cline { 2 - 3 } M (\%) & $\begin{array}{r}42 \cdot 6 \\
6.4\end{array}$ & $\begin{array}{r}33 \cdot 1 \\
8.3\end{array}$ & $\begin{array}{r}19 \cdot 6 \\
57.8\end{array}$ & $\begin{array}{r}4.7 \\
27.5\end{array}$ \\
\hline Both sexes & 23.4 & 19.9 & 39.9 & 16.8 \\
\hline
\end{tabular}

educational attainments than females. The proportions of subjects in this Table who had gone beyond primary school included those who were at or had been through a university. One-hundred and twenty-eight males and 169 females, most of them aged 10 to 19 years, were still at school and were excluded in the occupation groupings. By far the largest proportion of females was in the unskilled occupation of petty trading, and of the unemployed members of this sex, $\mathbf{7 8 . 8} \%$ were entirely dependent on their husbands' income.

\section{Systolic}

\section{Blood Pressure Readings}

Figure 2 shows the frequency distributions of systolic blood pressures in the sample. The number of subjects has been expressed as percentages of the total in each age block. Readings ranged from 80 to $220 \mathrm{mmHg}$ in males and from 80 to $250 \mathrm{mmHg}$ in females. The widest pressure ranges were observed in the fifth and sixth decades in males and in the sixth and seventh decades in females.

\section{Diastolic Pressures}

Figure 3 shows the distributions of the diastolic readings. The readings extended from 20 to 135 $\mathrm{mmHg}$ in males and from 40 to $150 \mathrm{mmHg}$ in females. The highest value $(150 \mathrm{mmHg})$ was obtained on two symptomless women aged 55 and 58 years.

\section{Age and Sex Differences}

Table III and Fig. 4 show the trends of mean systolic and diastolic pressures with age for males and females. In the younger age groups both mean systolic and mean diastolic pressures tended to be higher in males than in females but, with advancing age, the converse became true. Thus, for the systolic pressures, the means for females over the age of 50 years were significantly higher $(\mathrm{P}<0.001)$ than those for males of the same age group. The differences between the diastolic readings of the two sexes in these older age groups were less obvious.

Among the females there was a progressive and almost linear rise in mean systolic pressure after the age of 29 years. 

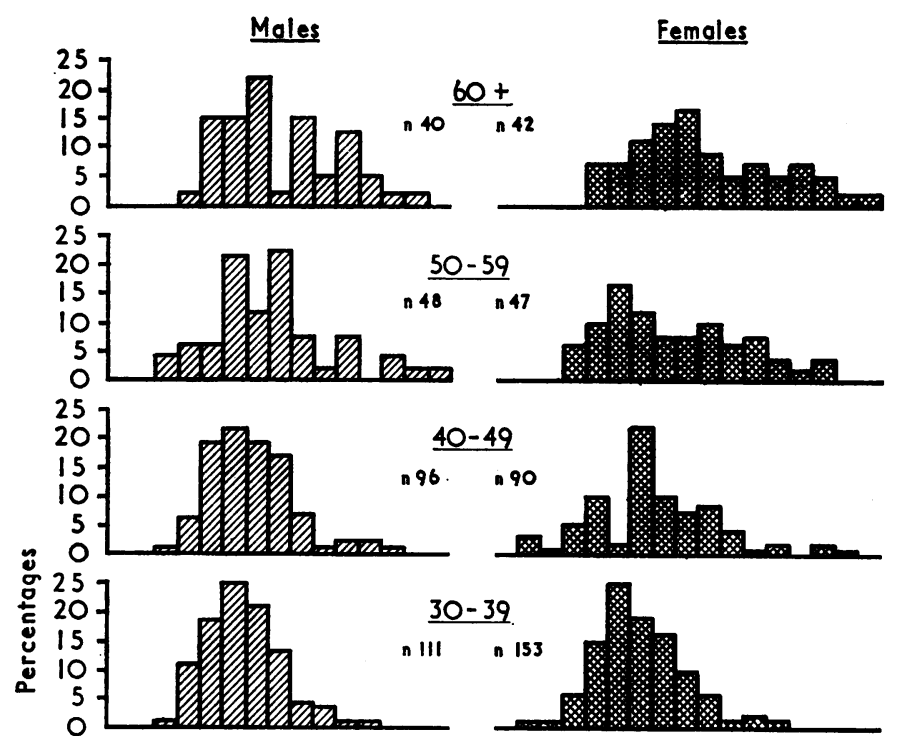

F10. 2. Frequency distribution of aystolic pres $\frac{\rho}{5}$ sures in difierent decades of both sexes.

Prevalence of Hypertension

Hypertension has been defined as a systolic blood pressure of $160 \mathrm{mmHg}$ or more or a diastolic pressure of $95 \mathrm{mmHg}$ or more or both (American Heart Association, 1960; W.H.O., 1962; Burgess, Fejfar and Kagan, 1963). Although the diastolic readings were taken in this study at phase IV, the author's experience in the field showed that in a number of the subjects studied phase IV coincided 3 with phase $\mathrm{V}$.

During the survey, the author encountered only? nine respondents (6 females and 3 males) all over the age of $\mathbf{4 5}$ years, who were previously known to be? hypertensives-an overall prevalence rate of $0.64 \%$. In none of these subjects were the initial pressure. readings taken in hospital by their physicians belowo

TABLE III

MEANS AND STANDARD DEVIATIONS OF SYSTOLIC AND DIASTOLIC PRESSURES BY AGE AND SEX

\begin{tabular}{|c|c|c|c|c|c|c|c|c|c|c|}
\hline \multirow{3}{*}{$\underset{\text { (years) }}{\text { Age Groups }}$} & \multirow[b]{3}{*}{$\mathbf{n}$} & \multicolumn{4}{|c|}{ Males } & & \multicolumn{4}{|c|}{ Females } \\
\hline & & \multicolumn{2}{|c|}{ Systolic } & \multicolumn{2}{|c|}{ Diastolic } & \multirow[b]{2}{*}{$\mathbf{n}$} & \multicolumn{2}{|c|}{ Systolic } & \multicolumn{2}{|c|}{ Diastolic } \\
\hline & & Mean & S.D. & Mean & S.D. & & Mean & S.D. & Mean & S.D. \\
\hline $\begin{array}{l}10-14 \\
15-19 \\
20-24 \\
25-29 \\
30-39 \\
40-49 \\
50-59 \\
60-69 \\
70 \text { and above }\end{array}$ & $\begin{array}{r}73 \\
77 \\
95 \\
102 \\
111 \\
96 \\
48 \\
27 \\
13\end{array}$ & $\begin{array}{l}109 \cdot 2 \\
124 \cdot 3 \\
130 \cdot 0 \\
128 \cdot 2 \\
133.0 \\
136.4 \\
143.9 \\
145 \cdot 2 \\
159 \cdot 2\end{array}$ & $\begin{array}{l}12.0 \\
17.0 \\
15.1 \\
15.6 \\
17.2 \\
24 \cdot 8 \\
24 \cdot 7 \\
22.7 \\
27.4\end{array}$ & $\begin{array}{l}69 \cdot 7 \\
78 \cdot 8 \\
83 \cdot 7 \\
82 \cdot 7 \\
86.4 \\
89.9 \\
89 \cdot 5 \\
92 \cdot 4 \\
90 \cdot 8\end{array}$ & $\begin{array}{l}10.2 \\
11.8 \\
11.1 \\
14.2 \\
10.9 \\
14.0 \\
14.6 \\
14.7 \\
10.3\end{array}$ & $\begin{array}{r}126 \\
94 \\
93 \\
105 \\
153 \\
90 \\
47 \\
20 \\
22\end{array}$ & $\begin{array}{l}113.4 \\
125.4 \\
122.5 \\
121.6 \\
129.5 \\
143.2 \\
154.8 \\
164.0 \\
169.8\end{array}$ & $\begin{array}{l}12.2 \\
13.6 \\
15.1 \\
15.8 \\
20.5 \\
27.3 \\
33.4 \\
30.4 \\
32.1\end{array}$ & $\begin{array}{l}71 \cdot 7 \\
78.8 \\
75.9 \\
78.1 \\
81.7 \\
90.7 \\
92.1 \\
97.0 \\
98.0\end{array}$ & $\begin{array}{l}16.6 \\
10.0 \\
13.7 \\
10.8 \\
13.6 \\
15.6 \\
17.7 \\
13.4 \\
19.5\end{array}$ \\
\hline
\end{tabular}




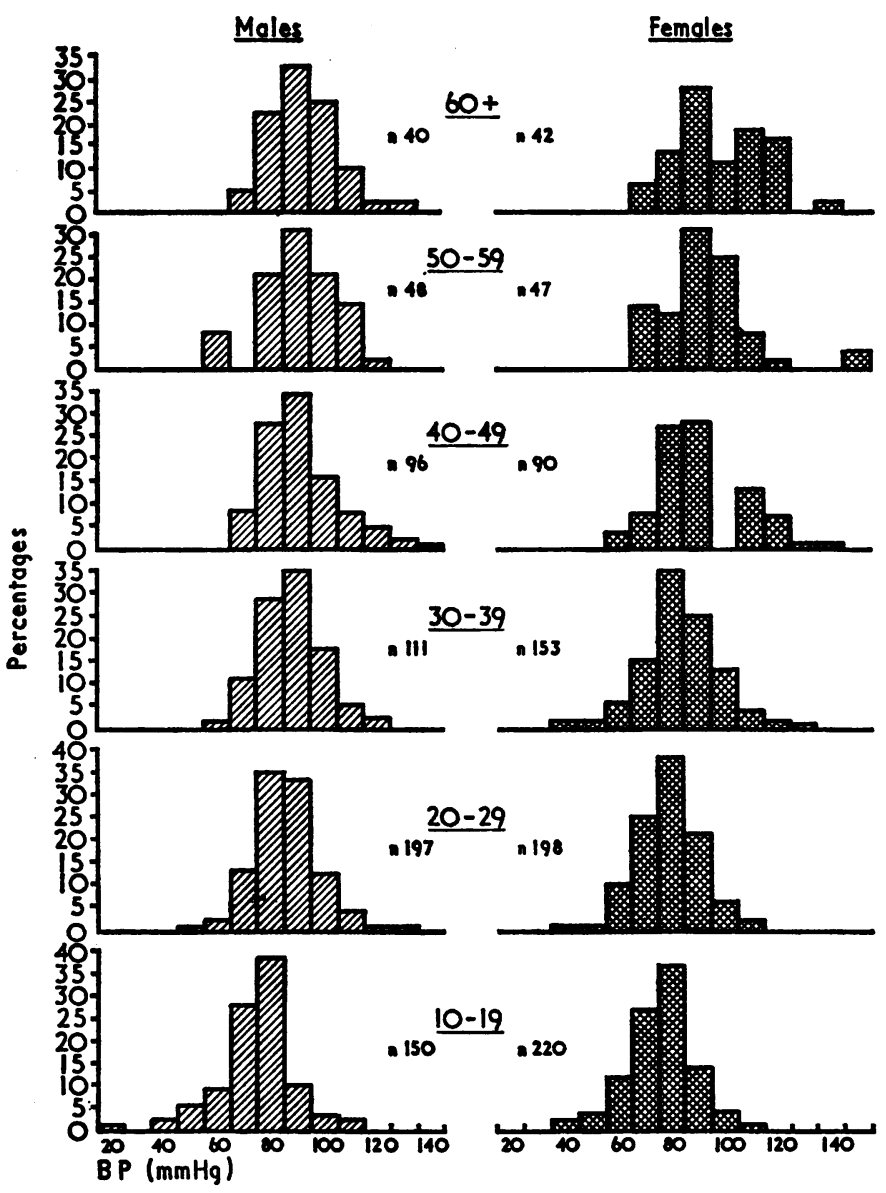

FiG. 3. Frequency distribution of diastolic pressures in different decades of both sexes.

$100 \mathrm{mmHg}$ diastolic and $180 \mathrm{mmHg}$ systolic.

Table IV shows the prevalence of hypertension by age and sex in this population sample according to several criteria. Systolic hypertension-systolic 160 $\mathrm{mmHg}$ and above, diastolic below $95 \mathrm{mmHg}$
(American Heart Association, 1960)-was commoner among females than males. The prevalence of hypertension (BP $160 / 100 \mathrm{mmHg}$ and above) rose with age in both sexes, and females in the older age groups had significantly higher rates than males.

TABLE IV

PREVALENCE OF 'HYPERTENSION' BY AGE AND SEX IN URBAN NIGERIANS, ACCORDING TO SEVERAL CRITERIA

\begin{tabular}{|c|c|c|c|c|c|c|c|c|}
\hline \multirow[b]{2}{*}{$\begin{array}{l}\text { Age Group } \\
\text { (years) }\end{array}$} & \multicolumn{4}{|c|}{ Males } & \multicolumn{4}{|c|}{ Females } \\
\hline & $\begin{array}{c}\text { Systolic } \\
\text { Hypertension }\end{array}$ & $\begin{array}{c}\text { Systolic } \\
160 \mathrm{mmHg}\end{array}$ & $\begin{array}{c}\text { Diastolic } \\
100 \mathrm{mmHg}\end{array}$ & Both & $\begin{array}{c}\text { Systolic* } \\
\text { Hypertension }\end{array}$ & $\begin{array}{c}\text { Systolic } \\
160 \mathrm{mmHg}\end{array}$ & $\begin{array}{l}\text { Dinstolic } \\
100 \mathrm{mmHg}\end{array}$ & Both \\
\hline $\begin{array}{l}10-19 \\
20-29 \\
30-39 \\
40-49 \\
50-59 \\
60-69 \\
70 \text { and above }\end{array}$ & $\begin{array}{r}1 \cdot 3 \\
0.5 \\
0.9 \\
0 \cdot 0 \\
2 \cdot 1 \\
0 \cdot 0 \\
23 \cdot 1\end{array}$ & $\begin{array}{r}2.7 \\
5.1 \\
9.9 \\
13.5 \\
22.9 \\
33 \cdot 3 \\
53 \cdot 8\end{array}$ & \begin{tabular}{r|}
$3 \cdot 3$ \\
9.1 \\
$17 \cdot 1$ \\
$25 \cdot 0$ \\
$35 \cdot 4$ \\
$37 \cdot 0$ \\
$30 \cdot 8$
\end{tabular} & $\begin{array}{r}1 \cdot 3 \\
3 \cdot 0 \\
7 \cdot 2 \\
12 \cdot 5 \\
20 \cdot 8 \\
33 \cdot 3 \\
30 \cdot 8\end{array}$ & $\begin{array}{r}0.5 \\
1.0 \\
2.6 \\
2.2 \\
6.4 \\
15.0 \\
13.6\end{array}$ & $\begin{array}{r}0.9 \\
3.5 \\
10.5 \\
26.7 \\
42.6 \\
65.0 \\
59.1\end{array}$ & $\begin{array}{r}3 \cdot 6 \\
6 \cdot 1 \\
12 \cdot 4 \\
32 \cdot 2 \\
38 \cdot 3 \\
50 \cdot 0 \\
50 \cdot 0\end{array}$ & $\begin{array}{r}0.5 \\
2.5 \\
7.2 \\
24.4 \\
34.0 \\
45.0 \\
45.5\end{array}$ \\
\hline All ages & 1.2 & $10 \cdot 1$ & $15 \cdot 1$ & 7.9 & $2 \cdot 4$ & $12 \cdot 7$ & $14 \cdot 3$ & 9.9 \\
\hline
\end{tabular}

- See text for definition. 


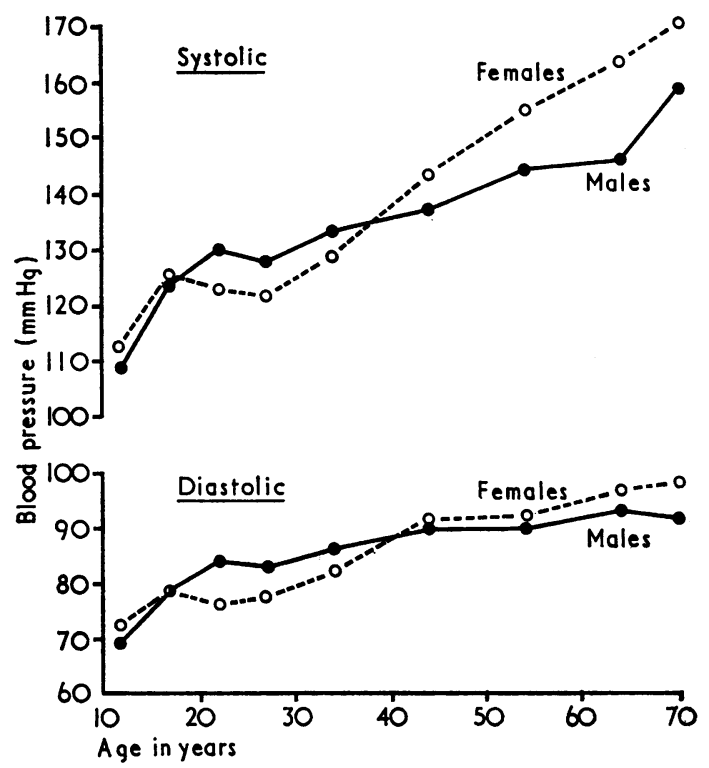

FIG. 4. Trends of systolic and diastolic pressures with age (male and female).

Familial OCcurrence of Hypertension

The word family was taken in the strict sense to mean first-degree relations (siblings, father, mother, and children) and not in the usual sense of the extended family system of most African communities.

\section{Blood Pressures in Parents and Offspring}

The blood pressure data on 108 spouses with children aged 15 years and above were analysed. The average ages of the fathers (age range 36 to 76 years) and mothers (age range 33 to 69 years) were $55.0( \pm 10.0)$ and $46.4( \pm 7.4)$ years respectively and all except two (aged 43 and 46 years) of their 159 children were in the age group 15 to 39 years. Table $V$ shows the occurrence of hypertension in parents and offspring.

Only one of the 38 children of the normotensive parents was hypertensive as compared with nine of the 42 children of hypertensive spouses. When only

TABLE V

OCCURRENCE OF HYPERTENSION IN PARENTS AND OFFSPRING

\begin{tabular}{l|cc}
\hline \multicolumn{1}{c|}{$\begin{array}{c}\text { B.P. Status and No. of } \\
\text { Parent Pairs }\end{array}$} & B.P. Status and No. of Offspring \\
\cline { 2 - 3 } & Normotensive & Hypertensive \\
\hline $\begin{array}{c}\text { Both hypertensive } \\
\mathrm{n}=19 \\
\text { Both normotensive } \\
\mathbf{n}=27 \\
\begin{array}{c}\text { Father or mother hypertensive } \\
\mathbf{n}=62\end{array}\end{array}$ & 33 & 9 \\
\hline
\end{tabular}

one of the parents was hypertensive the prevalence rate of hypertension among offspring was $5.7 \%$.

\section{Blood Pressure in Siblings}

From the records in the field the first subject in each sibship was taken as the propositus. As the analysis was confined to siblings aged 30 years anç above, the number of sibships in the population sur $\frac{\bar{c}}{\mathrm{c}}$ veyed was reduced to 49 and the maximum number of persons in each sibship did not exceed four. Of the 49 propositi, 33 had blood pressures in the des fined hypertensive range. Twenty (i.e., $60.6 \%$ ) of these hypertensive propositi each had at least one other hypertensive brother or sister but, of the $1 \overrightarrow{\mathrm{w}}$ normotensive propositi, six (i.e. $3 \cdot 8 \%$ ) had at least one hypertensive sibling.

\section{Discussion}

In Fig. 5 mean pressures of the present study are compared with those of surveys among Caucasianso

The systolic pressure data of Master Dublin, and Marks (1950) taken on American subjects are muchlower than those of the urban Nigerians, but the more recent figures in the Tecumseh study (Johnson? Epstein, and Kjelsberg, 1965) are rather similar. The Bergen data (Bøe, Humerfelt, and Wedervang, 1957), which were taken in two different districts aade were analysed separately by the authors because of -7 the unexplained differences found, have been ploted as different lines. They span the Lagos data Fors males and females. In the older age groups, mean systolic values in Lagos are lower among males but higher among females than those of the Britisho subjects studied by Hamilton, Pickering, Roberts and Sowry (1954a). The younger Nigerian males have definitely higher mean values than the British subjects. The growth of pressure with age is somewhat similar in all groups.

The diastolic curves for males show that the Lagos values (readings at phase IV) are very closely? similar to those of Johnson et al. (1965)_readings at phase IV-on Americans. Mean pressures for the Nigerian males and females are, however, distinctly higher in almost all the age groups than those of Hamilton et al. (1954a)-readings at phase IV-on British subjects. Bøe and his colleagues recorded the diastolic readings at phase $V$, except in caseswhere this was not distinct when the pressures were 0 taken at phase IV.

It was of considerable interest to compare the results on Negroes in America (Comstock, 1957) and the West Indies (Miall, Kass, Ling, and Stuart 1962), the ancestors of most of whom came frone West Africa in the seventeenth and eighteenth centuries, with those of the urban West African ${ }^{\text {P }}$ Negroes of this study and urban Zulus of South 
Fig. 5. Mean blood pressures in Caucasians and urban Nigerians.

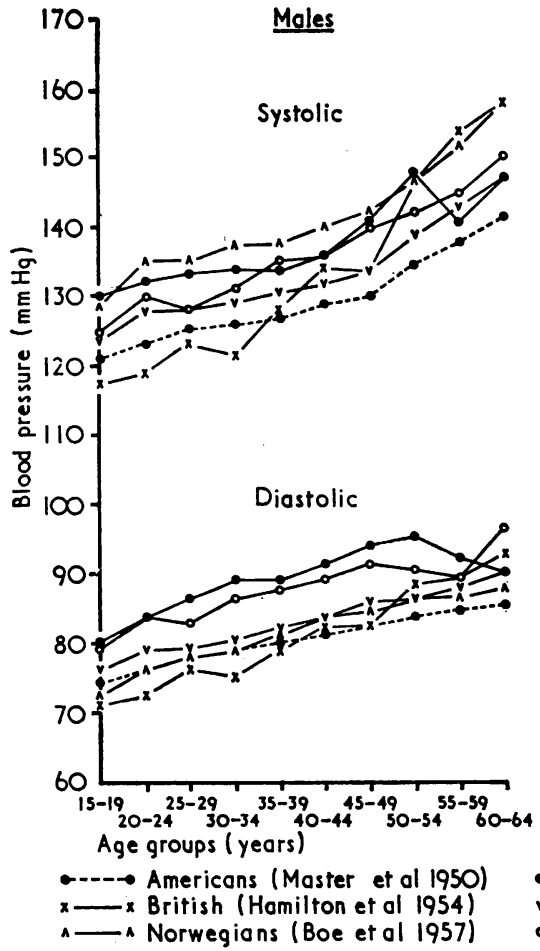

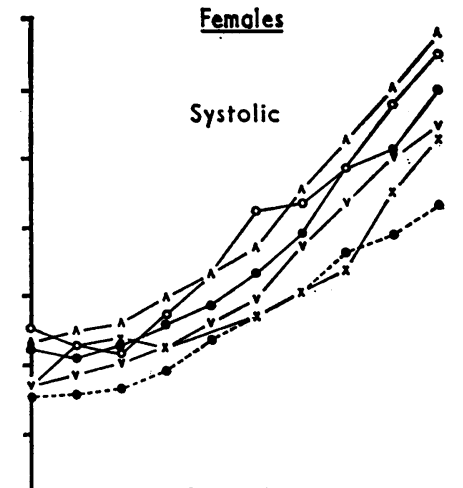

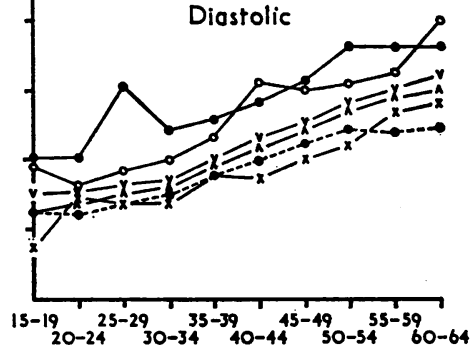

$\because$ Americans (Johnson et al 1965) $\multimap$ Urban Nigerions (Present study 19681

TABLE VI

Africa (Scotch, Gampel, Abramson, and Slome, 1961) (see Fig. 6). Mean blood pressures are lower in the Negroes of the Lagos Sample than in the Negro Americans of Comstock's study, but, except in a few age groups, the Lagos values are not very different from those of West Indian Negroes or those of the urban Zulus of South Africa.

The prevalence of hypertension among urban Nigerians is compared with that among Negroes and white Americans (National Center for Health Statistics, 1966) in Table VI. A limitation of this comparison must be pointed out; the minimum diastolic level (at phase IV) employed in the present study was $100 \mathrm{mmHg}$ and not $95 \mathrm{mmHg}$ (at phase $\mathrm{V})$, as in the American study.

In white Americans, up to the age of 55 years, hypertension appears more commonly in males than in females. This trend is absent in the two Negro groups, but in all these three groups the overall prevalence rates of hypertension are similar among males and females. In the youngest age group (15 to 24 years) Nigerians have the highest prevalence rates of the three groups and in all the other age groups they also have higher rates than the American white subjects. Hypertension appears to be more common among Nigerian men aged 45 to 54 years and women aged 55 to 64 years than among

FREQUENCY OF NIGERIAN AND AMERICAN * (WHITE AND NEGRO) ADULTS WITH HYPERTENSION, i.e. SYS. TOLIC PRESSURE $160 \mathrm{mmHg}$ OR DIASTOLIC PRESSURE $95 \mathrm{mmHg}$ (IN AMERICANS), $100 \mathrm{mmHg}$ (IN NIGERIANS) OR BOTH

\begin{tabular}{|c|c|c|c|c|c|c|}
\hline \multirow{3}{*}{$\begin{array}{c}\text { Age Group } \\
\text { (years) }\end{array}$} & \multicolumn{6}{|c|}{ Percentages } \\
\hline & \multicolumn{3}{|c|}{ Males } & \multicolumn{3}{|c|}{ Females } \\
\hline & White & Negro & Nigerian & White & Negro & Nigerian \\
\hline $\begin{array}{l}15-24 \\
25-34 \\
35-44 \\
45-54 \\
55-64 \\
65-74 \\
75 \text { and over }\end{array}$ & $\begin{array}{r}2 \\
4 \\
12 \\
17 \\
21 \\
27 \\
40\end{array}$ & $\begin{array}{l}2 \\
12 \\
26 \\
31 \\
45 \\
66 \\
60\end{array}$ & $\begin{array}{r}8 \\
10 \\
21 \\
35 \\
38 \\
35 \\
50\end{array}$ & $\begin{array}{r}1 \\
2 \\
6 \\
15 \\
31 \\
49 \\
45\end{array}$ & $\begin{array}{r}3 \\
8 \\
26 \\
42 \\
41 \\
71 \\
69\end{array}$ & $\begin{array}{r}5 \\
9 \\
23 \\
32 \\
56 \\
64 \\
50\end{array}$ \\
\hline All ages & 15 & 28 & 17 & 16 & 28 & 17 \\
\hline
\end{tabular}

-U.S.P.H.S. (1966)

their Negro counterparts in the United States. The similarities in the overall rates of hypertension between these Nigerians and the white American subjects may be a reflection of the age structure of the communities examined, the Nigerian sample representing the youngest population.

In an earlier study, I showed (Johnson, 1970a) that the average Nigerian male of the 'Lagos Sample' was heavier for height than the average white American male, and that at all ages the 


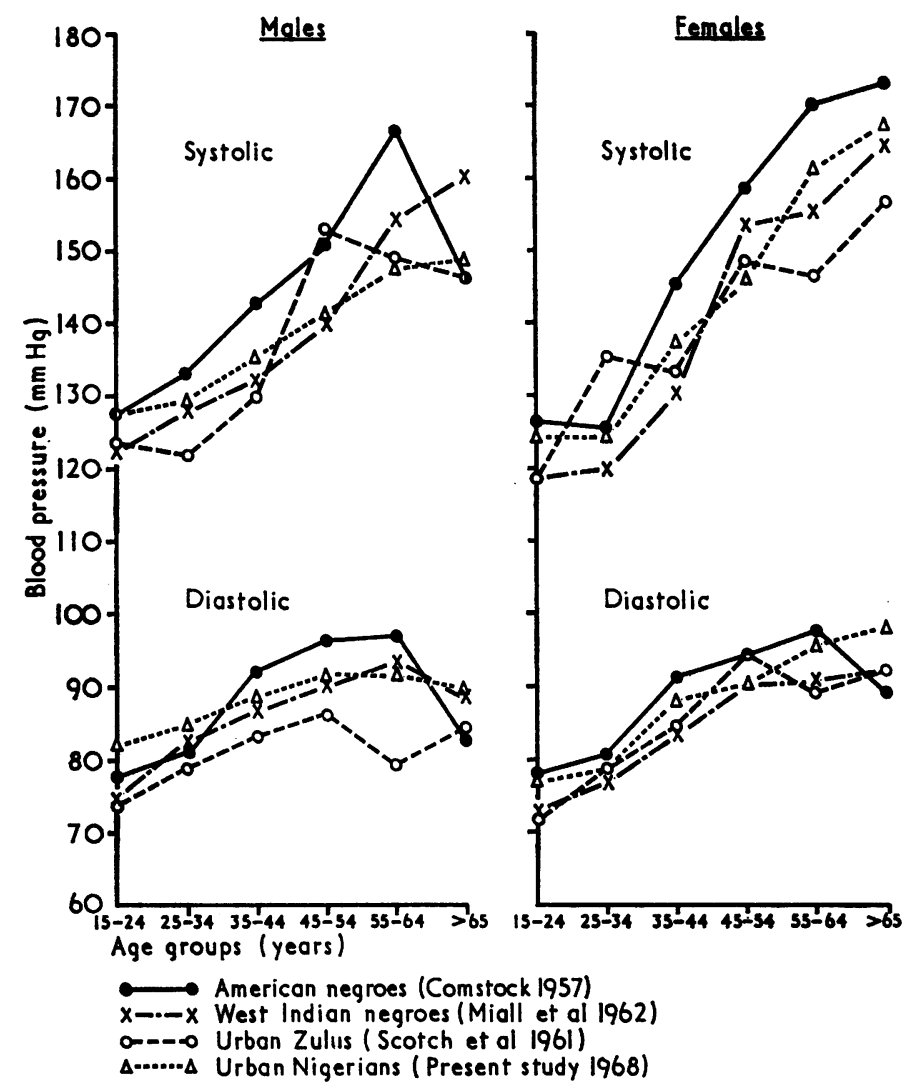

Fig. 6. Mean blood pressures in American and West Indian Negroes and urban Africans.

heights and weights of the Nigerian females were lower than those of white American females. Hathaway and Foard (1960) found that American Negro women were heavier than white females of corresponding heights, but differences between their male counterparts were minor. It does not appear, therefore, that differences in physique would explain the differences in rates of hypertension between these Nigerians and the American white and Negro subjects. In this respect Shaper and Saxton (1969) showed that, although rural Bagandans of Uganda were considerably lighter in body bulk than American white subjects, they exhibited virtually the same pattern of blood pressure levels at all ages and approximately the same prevalence of hypertension.

Among Europeans and Americans, there is suggestive evidence of a familial tendency to hypertension (Weitz, 1923; Ayman, 1934; Søbye, 1948; Morrison and Morris, 1960; Hamilton et al., 1954a, 1963; Platt, 1963; Miall and Oldham, 1963; Johnson et al., 1965). To my knowledge, this factor has not been examined in Africans. The method employed for the analysis in this study has as its basis a concept of 'normal' and 'abnormal' pressure levels derived by specific cut-off points and has at least the advantage of early and wide usage.

Ayman (1934), studying blood pressure in 1,524? members of 277 families, found that the prevalence 3 . of hypertension (B.P. over $140 / 80 \mathrm{mmHg}$ ) in offspring aged 14 to 39 years was $3.1 \%$ if no parent had hypertension, $28.3 \%$ if one parent had hyper-o tension, and $45.5 \%$ if both parents had hypertension. These figures are much higher than those obtained $\frac{7}{0}$ in the present study in which hypertension was defined by higher blood pressure readings. The $N$ present study, however, shows that when both $N$ parents are hypertensive the chances that one or more of their offspring will also show hypertension ${ }^{\omega}$ are greater than if either or both parents are normotensive. The number of sibship sets analysed is small, but the results obtained also show that hypertension in this African milieu does run in families. 


\section{SUMMARY}

The distributions of arterial blood pressures recorded by the author on 1,392 adult Africans living in the urban environment of the Capital of the Federal Republic of Nigeria are described.

The overall prevalence of hypertension as defined was as common in females as in males, although there were age-specific differences between the two sexes. In both sexes the prevalence rates rose with age.

In so far as conclusions could be drawn from comparisons of data in different surveys, it appeared that mean blood pressures were higher and arterial hypertension was commoner in many age groups of this urban African commurity than in some Caucasian communities. They were, however, appreciably lower than among Negro subjects in the North American continent.

Data are presented which afford evidence for a familial factor in hypertension in these subjects, but elucidation of the modes of its inheritance must await the results of more extensive family studies.

I wish to express my thanks to Dr. C. C. AdeniyiJones, Acting Head of the Department of Community Health of the College of Medicine, University of Lagos, for permission to study the subjects of the 'Lagos Sample', and to Dr. R. W. Morgan, Ph.D., for the random selection of the areas of study.

\section{REFERENCES}

AkInkUGBe, O. O. (1968). The rarity of hypertensive retinopathy in the African. Amer. J. Med., 45, 401. (1969). Hypertensive disease in Ibadan, Nigeria-a clinical prospective study. E. Afr. med. J., 46, 313.

american Heart association-National Heart INSTITUTE (1960). Epidemiology of cardiovascular diseases. Methodology. Amer. J. publ. Hlth, 50, No. 10, Suppl.

AYman, D. (1934). Heredity in arteriolar (essential) hypertension: a clinical study of the blood pressure of 1,524 members of 277 families. Arch. intern. Med., $53,792$.

Bøe, J., Humberfelt, S., and Wedervang, F. (1957). The blood pressure in a population. Acta med. scand., Suppl. 321.

Burgess, A. M., Fejfar, Z., and Kagan, A. R. (1963). Arterial Hypertension and Ischaemic Heart Disease. World Health Organization, Geneva.

Comstock, G. W. (1957). An epidemiologic study of blood pressure levels in a biracial community in the southern United States. Amer. J. Hyg., 65, 271.

Donnison, C. P. (1929). Blood pressure in the African native. Lancet, 1, 6.

Federal Department of Statistics (1963). Population Census of Nigeria's Federal Territory of Lagos, 1963.

Hamilton, M., Pickernng, G. W., Roberts, J. A. F., and SoWRY, G. S. C. (1963). Arterial pressures of relatives of patients with secondary and malignant hypertension. Clin. Sci., 24, 91.

- - - - and - (1954a). The aetiology of essential hypertension. 1. The arterial pressure in the general population. Clin. Sci., 13, 11.

,--1, and $-(1954 \mathrm{~b})$. The aetiology of essential hypertension. 4. The role of inheritance. Clin. Sci., 13, 273.

HATHAWAY, M. L., and FOARD, E. D. (1960). Heights and Weights of Adults in the United States. Home Econ. Res. Rep. No. 10, U.S. Dept. Agriculture, Washington, D.C.

Johnson, B. C., Epstein, F. H., and KJelsberG, M. O. (1965). Distributions and familial studies of blood pressure and serum cholesterol levels in a total community-Tecumseh, Michigan. J. chron. Dis., 18, 147.

JoHnson, T. O. (1970a). Height and weight patterns of an urban African population sample in Nigeria. Trop. geogr. Med., 22, 65.

- (1970b). Prevalence of overweight and obesity among adult subjects of an urban African population sample. Brit. J. prev. soc. Med., 24, 105.

KENNEY, R. A., and WATKINS, E. S. (1956). A comparison of the tilt-table responses of Africans and Europeans resident in the tropics. W. Afr. med J., n.s., 5, 112.

MASTER, A. M., DUBlin, L. I., and MARKS, H. H. (1950). The normal blood pressure range and its clinical applications. J. Amer. med. Ass., 143, 1464.

Miall, W. E., Kass, E. H., Ling, J., and Stuart, K. L. (1962). Factors influencing arterial pressure in the general population in Jamaica. Brit. med. J., 2, 497. , and OLDHAM, P. D. (1963). The hereditary factor in arterial-blood pressure. Brit. med. J., 1, 75.

Morgan, R. W. (1967). Personal communication.

Morrison, S. L., and Morris, J. N. (1960). Nature of essential hypertension. Lancet, 2, 829.

National Center for Health Statistics (1966). Hypertension and Hypertensive Heart Disease in Adults, United States 1960-62. P.H.S. Pub. No. 1000, Ser. 11, No. 13. U.S. Govt. Printing Office, Washington.

Platt, R. (1963). Heredity in hypertension. Lancet, 1, 899.

Scotch, N., Gampel, B., Abramson, J. H., and Slome, C. (1961). Blood pressure measurements of urban Zulu adults. Amer. Heart J., 61, 173.

Shaper, A. G., and SAXton, G. A. (1969). Blood pressure and body build in a rural community in Uganda. E. Afr. med. J., 46, 228.

SøвYE, P. (1948). Heredity in essential hypertension and nephrosclerosis. A genetic study of 200 propositi suffering from nephrosclerosis. Op. Domo Biol. hered. hum. (Kbh.), 16.

Sympostum on Blood Pressure and Hypertension in Africa (1969). Edited by A. G. Shaper. E. Afr. med. J., 46, No. 5.

VINT, F. W. (1937). Post-mortem findings in the natives of Kenya. E. Afr. med. J., 13, 332.

WerTz, W. (1923). Zur Ätiologie der genuinen oder vasculären Hypertension. Z. klin. Med., 96, 151.

World Health Organization (1962). Arterial Hypertension and Ischaemic Heart Disease. Wld Hlth Org. techn. Rep. Ser. No. 231. 